The actual words of the report are :-

The attention of the committee has been drawn to the fact that students may now matriculate at the Universities of Manchester, Liverpool, Leeds, Sheffeld, and Birmingham without passing in Latin.

Nothing is said of medical students or of the medical faculty. At the Comitia of this College, when this report was discussed and adopted, the fact that the University of Manchester required Latin in addition for its medical degrees was pointed out by the President. But that matriculation in other faculties can be taken at Manchester without Latin, may be seen from the University Calendar, where Latin is in the list of optional subjects.

The point of the committee's report was that the Conjoint Board having for 13 years accepted, as a preliminary to medical studies, the matriculation examination of the University of London without Latin, should, as a matter of common sense, recognise a similar examination in other Univer. sities.

I am, Sir, yours faithfully,

$$
\text { J. A. ORMEROD, }
$$

Royal College of Physicians, London, S.W., Feb. 17th, 1916.

\section{INVERSION OF THE PELVIC BONES.}

To the Editor of THE LANCET.

SIR,-I am glad Professor Elliot Smith recognised in your issue of Feb. 19th that I had fully acknow. ledged in my paper $\mathrm{my}$ "indebtedness to Dr. Douglas E. Derry's and Professor Wood Jones's work." He tacitly concedes my remark on the use of the well-known term "inversion," but I hasten to add that Professor Wood Jones made it quite clear to me in his contribution to the Nubian Monograph that his interesting cases were really due to the presence of a male element in the pelvis and caused delay in labour. The mere term is of little importance. I still hold that Zaaijer deserves credit for his work on the sulcus preauricularis, as Dr. Douglas E. Derry pointed out.

I hope that this discussion will direct the attention of obstetricians to the valuable facts of Professor Elliot Smith's and Professor Wood Jones's mono. graph, and especially to the great significance of the lateral aspect of the pelvis. Hitherto this view of the pelvis has been little figured or considered.

I am, Sir, yours faithfully,

Edinburgh, Feb. 21st, 1916.

D. BERR y HART.

\section{ULCERS NEW AND OLD.}

To the Editor of THE LANCET.

SIR,-As gastric ulcer has a wide range of dis. tribution I take it that ulceration at any point of the prima via is of interest now that Sir John Bland-Sutton has so much enlightened us in his Hunterian lecture on this subject. ${ }^{1}$

In 1899 I was consulted by a lady, aged 56, married, who had been the subject of chronic dyspepsia for some years, characterised by pain after food, weight, eructation, and gnawing discomfort; the locality varied, but always pointed to the umbilicus. The usual remedies of bismuth and alkalies generally relieved her attacks. In the intervals of attendance she took "Cockle's pills." There was no history of anæmia, of thrombosis, or of hæmorrhage, and her attacks were set down to stercoral or toxic states. Added to her symptoms in August, 1899, she had severe colic and constipa. tion, for the relief of which I prescribed an oily emulsion of castor oil ( $\zeta$ ss.), olive oil ( $\left.\zeta 1 \frac{1}{2}\right)$, and clove

1 The Lascer, Feb. 19th, 1916, p. 387. oil ( $\mathrm{mi}$. ). Immediate relief followed on the ensuing morning, but later on in the same day she was taken with all the signs of perforation, with chymous, and later stercoral, vomit, acute pain, a fixed diaphragm. critical sweating, and every indication of approach. ing death. A surgeon was summoned, but arrived four hours too late. A post.mortem examination (in which I was assisted by Dr. Howard 0. Davies) revealed a clean stercoral ulcer, circular, $\frac{1}{4}$ inch in diameter, through the longitudinal band of the transverse colon. All the coats of the gut but the peritoneal had long been eroded, and she had probably been saved a much earlier death by the unique site of the ulcer, unaffected by muscular action of a direct character. A serpentine outflow of pultaceous matter had taken place into the peritoneum. The specimen is now in the pathological museum of St. Mary's Hospital.

I am, Sir, yours faithfully, Herbert A. SMith, M.D.

Madeley-road, Ealing, W., Feb. 21st, 1916.

\section{THE EXAMINATION OF THE SOLDIER' HEART.}

To the Editor of THE LANCET.

SIR,-Since writing my note on this subject in THE LANCET of Feb. 5th, opportunity has been afforded me by the kindness of Major Parsons and Dr. Florence Stoney of examining eight cases of "soldier's heart." Dr. Stoney accompanied me. and at my request did not tell me anything about the patients until after I had concluded the exam. ination. Of these eight, in six the ratio of the first and second sound was normal, and therefore I concluded that the condition was not due to any infection; but in the other two, the ratio was 1 instead of 2. Dr. Stoney told me that of these two cases one had had dysentery; of the six cases of normal ratio tromble had followed shell-shock. The remaining case with an altered ratio had been ill for more than 12 months, and showed most of the signs of a well-marked case of Graves's disease. I am, Sir, yours faithfully,

Portland-place, W., Feb. 16th, 1916.

O. LEYTON.

\section{A DAUGHTER OF THE LATE SIR JOHN HUMPHREYS. \\ To the Editor of THE LANCET.}

SIR,-I shall be grateful if you will allow me to make an appeal on behalf of a very interesting case. Doubtless many of your readers will remember the late Sir John Humphreys. He died 20 years ago, was coroner for Middlesex and a colleague of the former Editor of THE LANCET. Perhaps among your readers there are some of his old friends who still remember his personality and attainments. It is on behalf of Sir John Humphreys's daughter, Mrs. Ellen Hunt Foulston, that $I$ wish to appeal. She is a candidate for a pension from the Royal Hospital for Incurables, Putney Heath. The next election will be held in May. She is an incurable invalid, crippled with rheu. matoid arthritis, and in the autumn of her life she has been left without any income whatever. Her sole means of support are derived from a few old friends, but this, with all the generosity they have shown. cannot be regarded as permanent. I am aware that, for success at an election of the Royal Hospital for Incurables about 1400 or 1500 votes are necessary, and, large as this number is, I think there should not be great difficulty in securing them for Mrs. Hunt Foulston. I shall be happy to send some of the candidate's cards to 